\title{
Comparison of In-Hospital Outcomes of ST Elevation Myocardial Infarction in Patients Undergoing Transradial and Transfemoral Primary Percutaneous Coronary Intervention
}

\author{
Fahdia Afroz' ${ }^{1}$, Mir Jamal Uddin ${ }^{1}$, Md. Khalquzzaman ${ }^{1}$, Mohammad Ullah ${ }^{1}$, Mohammad Khalilur \\ Rahman Siddiqui' ${ }^{2}$, Shakur Ahmed ${ }^{1}$, Abul Khair ${ }^{1}$, Md. Rezawanul Islam ${ }^{1}$, Md. Minhaj Arefin ${ }^{1}$, \\ Fathima Aaysha Cader ${ }^{1}$, Mohammad Arifur Rahman ${ }^{1}$ \\ ${ }^{1}$ National Institute of Cardiovascular Diseases, ${ }^{2}$ Cumilla Medical College Hospital, Cumilla
}

\begin{abstract}
Key Words: Ischaemic heart disease, STEMI, Percutaneous coronary intervention.

Background: Primary percutaneous coronary intervention (PPCI) has been performed traditionally by using femoral approach. Transradial approach has become increasingly popular as it is likely to be less complicating, more comfortable and relatively cost effective having mortality and morbidity benefits. The aim of the study was to compare the in-hospital outcomes of transradial PPCI with that of transfemoral route.

Methods: A total of 80 patients with ST elevation myocardial infarction (STEMI) who underwent PPCI were enrolled in the study. Patients were divided in two groups. Group-I: transradial PPCI; and Group-II: transfemoral PPCI. All patients were followed up during the period of hospital stay and adverse outcomes were observed and compared between the groups.

Results: The result showed that bleeding took place in 2.5\% patient of Group-I and $15 \%$ patients of GroupII. Vascular complications occurred in $2.5 \%$ and $12.5 \%$ patients of Group-I and Group-II, respectively. In Group-II, 7.5\% patients died with none in Group-I. In Group-II, 37.5\% patients experienced some sort of adverse outcomes whereas only $15 \%$ of the patients of Group-I did have such experiences $(p<0.05)$. Bleeding and vascular complications were significantly more in Group-II $(p<0.05)$. The mean hospital stay time was significantly lower in Group-I $(p<0.001)$.

Conclusions: Transradial PPCI is safer than transfemoral approach in respect of procedural and post procedural complications including bleeding, vascular complications and mortality. So, transradial approach may be an attractive alternative to conventional transfemoral approach and can be practiced routinely for PPCI.
\end{abstract}

(Cardiovasc. j. 2019; 11(2): 98-104)

\section{Introduction:}

The main goal of STEMI management is rapid reperfusion to establish coronary blood flow to ischemic myocardium. Currently, there are three main reperfusion strategies: fibrinolytic therapy, primary percutaneous coronary intervention (PPCI) and fibrinolytic-facilitated PPCI. ${ }^{1-3}$ The widespread use of PPCI dramatically improved the clinical outcomes of
STEMI and it has become the preferred treatment of this condition. ${ }^{2,4,5}$

Coronary interventions have been traditionally performed using the femoral approach for arterial access since its inception in 1977 to till date due to the fact that its size makes arterial cannulation and catheter manipulation easy. ${ }^{3,6}$ Despite these advantages, femoral access has several limitations. The femoral artery is

Address of Correspondence: Dr. Fahdia Afroz, Department of Cardiology, National Institute of Cardiovascular Diseases, Dhaka Bangladesh. Email: fahdia_afroz@yahoo.com

(C) 2018 authors; licensed and published by International Society of Cardiovascular Ultrasound, Bangladesh Chapter and Bangladesh Society of Geriatric Cardiology. This is an Open Access article distributed under the terms of the CC BY NC 4.0 (https:// creativecommons.org/licenses/by-nc/4.0). 
relatively deep, especially in obese patients, and its proximity to the femoral vein and nerve is a potential source of iatrogenic injury. ${ }^{7}$ In addition, prolonged bed rest is mandatory in this setting. ${ }^{4}$ Especially under conditions of aggressive anticoagulation and antiplatelet treatment, vascular bleeding complications at the femoral puncture site can result in increased morbidity and duration of hospitalization. . $^{8-10}$

Transradial approach has become increasingly popular day by day because it is associated with decreased incidence of hemorrhagic and vascular complications, increased patient comfort, earlier ambulation, earlier hospital discharge, and cost reduction. ${ }^{11}$ Transradial approach has some advantages over transfemoral approach. The radial artery is easily compressible, thus hemostasis is easier and haemorrhagic complications are significantly reduced. ${ }^{12}$ Moreover, no major veins or nerves are located near the artery, minimizing risk of injury to these structures. Finally, post procedure bed rest is not required, permitting immediate ambulation, more comfort and early discharge which improve quality of life of patients and reduced hospitalization cost. ${ }^{13-16}$ In Bangladesh no study was carried out regarding this issue. The aim of the present study was therefore to compare the in hospital outcomes of transradial and transfemoral PPCI.

\section{Methods:}

In the Department of Cardiology, National Institute of Cardiovascular Diseases, Dhaka, this prospective observational study was conducted during the period from August 2016 to April 2017. By purposive sampling technique total 80 patients who underwent PPCI in NICVD during this period were selected. Study subjects were divided into two groups with 40 patients in each on the basis of route of interventions: Group 1: Transradial group; Group 2: Transfemoral group. Patients who received thrombolytic therapy were not included. Patients with chronic kidney diseases, chronic liver disease, chronic obstructive pulmonary disease, valvular heart disease, congenital heart disease, cardiomyopathy, malignancy were excluded from the study. No ethical violation was made in conducting the study.
After having matched the inclusion and exclusion criteria the patients were selected for this study. Eligible patients immediately underwent for coronary angiogram according to operator's choice of route of intervention. Following PPCI patients were monitored at Coronary Care Unit for at least 24 hours. Post-PCI development of in-hospital left ventricular failure along with common adverse outcomes were observed and recorded, i.e., bleeding, stroke, vascular access site complications, post-PCI ischemic chest pain, myocardial infarction with PCI, significant arrhythmia, acute stent thrombosis, repeat revascularization, contrast induced nephropathy, cardiogenic shock, cardiovascular death.

Nature of the data was explored. Summary statistics of symmetric continuous data, expressed as mean \pm SD. Summary statistics for categorical variables were expressed as proportion or percentage. Comparisons between two groups were done by t-test. Correlation analyses were done by two-tailed Pearson's chisquare test. Fisher's exact test was carried out when cell frequency was $<5$. The prediction model was developed to correct for differences in patient and procedural characteristics treated by the radial and femoral route primary PPCI. In $95 \%$ confidence interval $\mathrm{P}$-value of $<0.05$ was considered as significant. Analysis was conducted on SPSS 16.0 for windows operating system.

\section{Results:}

The mean age of the study patients was $50.3 \pm 11.4$ years. The mean age difference was not statistically significant $(p>0.05)$ between two groups (Table-I). Male patients were predominant in both groups (Figure 1). The ratio of male and female patients was 4.7:1.

Table-II compares the common risk factors for coronary artery diseases between two groups. Smoking was found 13 (32.5\%) in the group I and $9(22.5 \%)$ patients in the group II and statistically insignificant $(\mathrm{p}=0.31)$. Hypertension was found 15 (37.5\%) and 20 (50\%) in the group I and group II respectively. The association was statistically insignificant $(\mathrm{p}=0.26)$. Diabetes mellitus was found $18(45 \%)$ and 22 (55\%) in the group I and group II respectively with statistically insignificant $(p=0.37)$ association. 
Table-I

Distribution of the study patients according to age $(N=80)$.

\begin{tabular}{|c|c|c|c|c|c|c|c|}
\hline \multirow{2}{*}{$\begin{array}{l}\text { Age in } \\
\text { years }\end{array}$} & \multicolumn{2}{|c|}{ Group I $(n=40)$} & \multicolumn{2}{|c|}{ Group II $(n=40)$} & \multicolumn{2}{|c|}{ Total $(\mathrm{N}=80)$} & \multirow[t]{2}{*}{$\mathrm{p}$ value } \\
\hline & Number & $\%$ & Number & $\%$ & Number & $\overline{\%}$ & \\
\hline$<40$ & 5 & 12.5 & 6 & 15.0 & 11 & 13.8 & \\
\hline $40-49$ & 12 & 30.0 & 9 & 22.5 & 21 & 26.2 & \\
\hline $50-59$ & 13 & 32.5 & 17 & 42.5 & 30 & 37.5 & \\
\hline$\geq 60$ & 10 & 25.0 & 8 & 20.0 & 18 & 22.5 & \\
\hline $\begin{array}{l}\text { Mean } \pm \text { SD } \\
\text { Range } \\
(\min -\max )\end{array}$ & \multicolumn{2}{|c|}{$\begin{array}{c}50.8 \pm 13.1 \\
(22-76)\end{array}$} & \multicolumn{2}{|c|}{$\begin{array}{c}49.8 \pm 9.6 \\
(30-71)\end{array}$} & \multicolumn{2}{|c|}{$\begin{array}{c}50.3 \pm 11.4 \\
(22-76)\end{array}$} & $0.69^{\mathrm{ns}}$ \\
\hline
\end{tabular}

Group I = Transradial approach, Group II = Transfemoral approach, ns = Not significant $(\mathrm{p}>0.05)$, $\mathrm{p}$ value reached from unpaired t-test

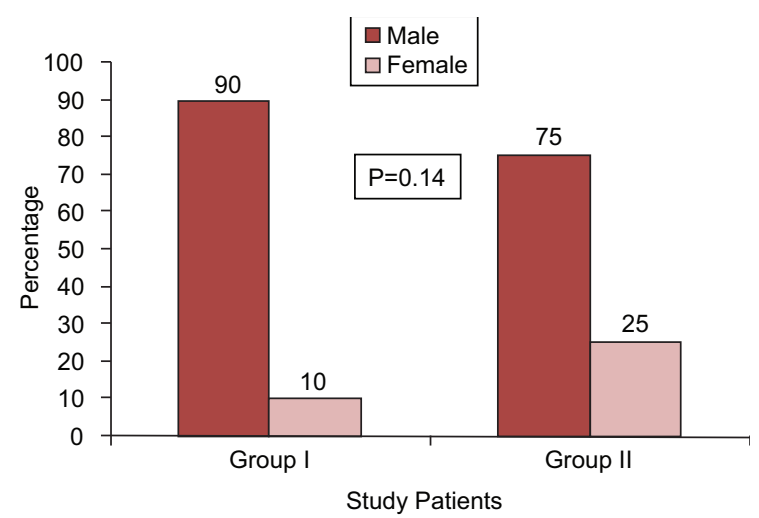

Fig.-1: Sex distribution of the study patients $(N=80)$.

Table-II

Distribution of patients according to risk factors.

\begin{tabular}{|c|c|c|c|c|c|c|c|}
\hline$\overline{\text { Risk }}$ & Group ] & & Group II & 40) & Total & & $p$ value \\
\hline factors` & Number & $\%$ & Number & $\%$ & Number & $\%$ & \\
\hline$\overline{\text { Smoking }}$ & 13 & 32.5 & 9 & 22.5 & 22 & 27.5 & $0.31^{\mathrm{ns}}$ \\
\hline Hypertension & 15 & 37.5 & 20 & 50.0 & 35 & 43.8 & $0.26^{\mathrm{ns}}$ \\
\hline $\begin{array}{l}\text { Diabetes } \\
\text { mellitus }\end{array}$ & 18 & 45.0 & 22 & $55.0^{6}$ & 40 & 50.0 & $0.37^{\mathrm{ns}}$ \\
\hline Dyslipidaemia & 7 & 17.5 & 11 & 27.5 & 18 & 22.5 & $0.28^{\mathrm{ns}}$ \\
\hline $\begin{array}{l}\text { Family history } \\
\text { of CAD }\end{array}$ & 13 & 32.5 & 16 & 40.0 & 29 & 36.2 & $0.48^{\mathrm{ns}}$ \\
\hline
\end{tabular}

Group I= Transradial approach, Group II= Transfemoral approach, ns = Not significant $(p>0.05), s=$ Significant $(p<0.05), p$ value reached from Pearson's Chi-square test and Fisher's exact test.

Dyslipidemia was higher in group II than group I $(27.5 \%$ vs. $17.5 \%)$ and the association was statistically insignificant $(\mathrm{p}=0.28)$. Family history of CAD had $13(32.5 \%)$ and $16(40 \%)$ in group I and group II respectively with statistically insignificant association $(\mathrm{p}=0.48)$.

The Table-III displays that the patients with anterior and inferior AMI were equally 
distributed in group I and group II with statistically insignificant difference $(p>1.05)$.

The Table-IV describes that vessel involvement among the study patients were almost similar with statistically insignificant difference between groups ( $>>0.05)$.

Table-V shows that the percentage of stenosis in culprit arteries were almost identical in between study groups $(p>0.05)$.

There was no significant $(\mathrm{p}>0.05)$ difference between the groups in terms of the arteries involved with coronary interventions (Table-VI).

The TIMI flow presented almost identical $(p>0.05)$ in group I and group II (Table-VII).

Table-VIII demonstrates that the hospital stay time was more in group II than group I patients which was about 6 days and 4 days, respectively.
The mean difference was statistically significant $(\mathrm{p}<0.001)$.

Table-IX shows that bleeding occurred 1 (2.5\%) in Group I and 6 (15\%) in Group II patients, Vascular complications occurred in $1(2.5 \%)$ and 5 (12.5\%) patients Group I and Group II respectively. No death observed in Group I and $3(7.5 \%)$ patients died in group II. So the bleeding and vascular complications were significantly occurred in Group II than in Group I with statistically significant $(p<0.05)$ association. The occurrence of other adverse outcomes were not varied statistically significantly $(\mathrm{p}>0.05)$.

Out of 40 patients, $37.5 \%$ patients in group II experienced overall adverse outcome, on the contrary $15 \%$ of the patients in group I did have such experience. So, the Table-XII revealed that overall outcome were less in group I than group II which is statistically significant $(p<0.05)$.

Table-III

Distribution of patients according to ECG diagnosis $(N=80)$.

\begin{tabular}{|c|c|c|c|c|c|c|c|}
\hline \multirow{2}{*}{$\begin{array}{l}\text { Clinical } \\
\text { diagnosis }\end{array}$} & \multicolumn{2}{|c|}{ Group I $(n=40)$} & \multicolumn{2}{|c|}{ Group II $(\mathrm{n}=40)$} & \multicolumn{2}{|c|}{ Total $(\mathrm{N}=80)$} & \multirow[t]{2}{*}{$\mathrm{p}$ value } \\
\hline & Number & $\%$ & Number & $\%$ & Number & $\%$ & \\
\hline Anterior & 21 & 52.5 & 21 & 52.5 & 40 & 100.0 & $1.00^{\mathrm{ns}}$ \\
\hline Inferior & 19 & 47.5 & 19 & $47.5^{6}$ & 40 & 100.0 & $1.00^{\mathrm{ns}}$ \\
\hline
\end{tabular}

Group I= Transradial approach, Group II= Transfemoral approach, ns = Not significant (p>0.05), $p$ value reached from Chi-square test

Table-IV

Distribution of patients according to coronary angiography $(N=80)$.

\begin{tabular}{|c|c|c|c|c|c|c|c|}
\hline \multirow{2}{*}{$\begin{array}{l}\text { No. of diseased } \\
\text { Vessels }\end{array}$} & \multicolumn{2}{|c|}{ Group I $(\mathrm{n}=40)$} & \multicolumn{2}{|c|}{ Group II $(\mathrm{n}=40)$} & \multicolumn{2}{|c|}{ Total $(\mathrm{N}=80)$} & \multirow[t]{2}{*}{$\mathrm{p}$ value } \\
\hline & Number & $\%$ & Number & $\%$ & $\overline{\text { Number }}$ & $\%$ & \\
\hline Single & 26 & 65.0 & 27 & 67.5 & 53 & 66.2 & $0.81^{\mathrm{ns}}$ \\
\hline Double & 11 & 27.5 & 11 & 27.5 & 22 & 27.5 & $1.00^{\mathrm{ns}}$ \\
\hline Triple & 3 & 7.5 & 2 & 5.0 & 5 & 6.3 & $0.81^{\mathrm{ns}}$ \\
\hline
\end{tabular}

Group I= Transradial approach, Group II= Transfemoral approach, ns= Not significant $(\mathrm{p}>0.05)$, $\mathrm{p}$ value reached from Chi square test and Fisher's exact test

Table-V

Percentage of stenosis in culprit artery $(N=80)$.

\begin{tabular}{lcccccc}
\hline Stenosis & \multicolumn{2}{c}{ Group I $(\mathrm{n}=40)$} & & \multicolumn{2}{c}{ Group II $(\mathrm{n}=40)$} & p value \\
\cline { 2 - 3 } & Number & Percent (\%) & & Number & Percent (\%) & \\
\hline $100 \%$ & 33 & 82.5 & & 32 & 80.0 & $0.77^{\mathrm{ns}}$ \\
$70-99 \%$ & 7 & 17.5 & & 8 & 20.0 & \\
\hline
\end{tabular}

Group I= Transradial approach, Group II= Transfemoral approach, ns = Not significant ( $>0.05)$, p value reached from Chi Square test 


\section{Table-VI}

Distribution of patients according to coronary interventions $(N=80)$.

\begin{tabular}{|c|c|c|c|c|c|c|c|}
\hline \multirow[t]{2}{*}{$\overline{\text { Intervention }}$} & \multicolumn{2}{|c|}{ Group I (n = 40) } & \multicolumn{2}{|c|}{ Group II $(\mathrm{n}=40)$} & \multicolumn{2}{|c|}{ Total $(\mathrm{N}=80)$} & \multirow[t]{2}{*}{$p$ value } \\
\hline & Number & $\%$ & Number & $\%$ & Number & $\overline{\%}$ & \\
\hline$\overline{\mathrm{LAD}}$ & 21 & 52.5 & 20 & 50.0 & 41 & 51.2 & $0.81^{\mathrm{ns}}$ \\
\hline LCX & 3 & 7.5 & 5 & 12.5 & 8 & 10.0 & $0.71^{\mathrm{ns}}$ \\
\hline $\mathrm{RCA}$ & 14 & 35.0 & 15 & 37.5 & 29 & 36.2 & $0.81^{\mathrm{ns}}$ \\
\hline Multi vessel & 2 & 5.0 & 0 & 0.0 & 2 & 2.5 & $1.00^{\mathrm{ns}}$ \\
\hline
\end{tabular}

Group I= Transradial approach, Group II= Transfemoral approach, ns= Not significant $(p>0.05)$, $p$ value reached from Chi square test Fisher's exact test

Table-VII

Procedural outcome of the study patients according to TIMI flow after primary PCI $(N=80)$.

\begin{tabular}{lcccccc}
\hline TIMI flow & \multicolumn{2}{c}{ Group I $(\mathrm{n}=40)$} & & \multicolumn{2}{c}{ Group II $(\mathrm{n}=40)$} & $\mathrm{p}$ value \\
\cline { 2 - 3 } & Number & Percent $(\%)$ & & Number & Percent $(\%)$ & \\
\hline 0 & 0 & 0.0 & & 0 & 0.0 & \\
I & 0 & 0.0 & & 0 & 0.0 & \\
II & 5 & 12.5 & & 7 & 17.5 & $0.53^{\text {ns }}$ \\
III & 35 & 87.5 & & 33 & 82.5 & $0.53^{\text {ns }}$ \\
\hline
\end{tabular}

Group I= Transradial approach, Group II= Transfemoral approach, ns = Not significant ( $p>0.05)$, p value reached from Chi Square test

Table-VIII

Comparison of the study patients according to hospital stay $(N=80)$.

\begin{tabular}{|c|c|c|c|c|c|c|c|}
\hline \multirow{3}{*}{$\begin{array}{l}\text { Hospital stay } \\
\text { (days) }\end{array}$} & \multicolumn{6}{|c|}{ Study patients } & \multirow[t]{3}{*}{$\mathrm{p}$ value } \\
\hline & \multicolumn{2}{|c|}{ Group I $(\mathrm{n}=40)$} & \multicolumn{2}{|c|}{ Group II (n = 40) } & \multicolumn{2}{|c|}{ Total $(\mathrm{N}=80)$} & \\
\hline & Number & $\%$ & Number & $\%$ & Number & $\%$ & \\
\hline$\leq 5$ days & 32 & 80.0 & 13 & 32.5 & 45 & 56.2 & \\
\hline$>5$ days & 8 & 20.0 & 27 & 67.5 & 35 & 43.8 & \\
\hline Mean \pm SD & \multicolumn{2}{|c|}{$4.4 \pm 2.2$} & \multicolumn{2}{|c|}{$6.3 \pm 2.9$} & \multicolumn{2}{|c|}{$8.4 \pm 3.7$} & $<0.001^{\mathrm{s}}$ \\
\hline
\end{tabular}

Table-IX

Comparison of the study patients by outcomes variables $(N=80)$.

\begin{tabular}{|c|c|c|c|c|c|c|c|}
\hline \multirow{2}{*}{$\begin{array}{l}\text { Outcomes } \\
\text { variables }\end{array}$} & \multicolumn{2}{|c|}{ Group I $(\mathrm{n}=40)$} & \multicolumn{2}{|c|}{ Group II $(n=40)$} & \multicolumn{2}{|c|}{ Total $(\mathrm{N}=80)$} & \multirow[t]{2}{*}{$p$ value } \\
\hline & Number & $\%$ & Number & $\%$ & Number & $\%$ & \\
\hline $\begin{array}{l}\text { Recurrent } \\
\text { ischemia }\end{array}$ & 0 & 0.0 & 1 & 2.5 & 1 & 1.2 & $1.00^{\mathrm{ns}}$ \\
\hline Bleeding & 1 & 2.5 & 6 & 15.0 & 7 & 8.8 & $0.04^{\mathrm{s}}$ \\
\hline $\begin{array}{l}\text { Vascular } \\
\text { complications }\end{array}$ & 1 & 2.5 & 5 & 12.5 & 6 & 7.5 & $0.04^{\mathrm{s}}$ \\
\hline Death & 0 & 0.0 & 3 & 7.5 & 3 & 3.8 & $0.07^{\mathrm{ns}}$ \\
\hline Cardiogenic shock & 2 & 5.0 & 5 & 12.5 & 7 & 8.8 & $0.43^{\mathrm{ns}}$ \\
\hline Heart failure & 1 & 2.5 & 3 & 7.5 & 4 & 5.0 & $0.61^{\mathrm{ns}}$ \\
\hline $\begin{array}{l}\text { Significant } \\
\text { arrhythmia }\end{array}$ & 6 & 15.0 & 3 & 7.5 & 9 & 11.2 & $0.28^{\mathrm{ns}}$ \\
\hline Stroke & 0 & 0.0 & 0 & 0.0 & 0 & 0.0 & \\
\hline
\end{tabular}

Group I= Transradial approach, Group II= Transfemoral approach,ns= Not significant $(p>0.05), s=$ Significant $(p<0.05)$, $p$ value reached from Chi-square test and Fisher's exact test 
Table-XI

Comparison of patients by composite or overall adverse outcome $(N=80)$.

\begin{tabular}{|c|c|c|c|c|c|c|c|}
\hline \multirow{2}{*}{$\begin{array}{l}\text { Adverse } \\
\text { in-hospital } \\
\text { outcome }\end{array}$} & \multicolumn{2}{|c|}{ Group I $(\mathrm{n}=40)$} & \multicolumn{2}{|c|}{ Group II $(n=40)$} & \multicolumn{2}{|c|}{ Total $(\mathrm{N}=80)$} & \multirow[t]{2}{*}{$\bar{p}$ value } \\
\hline & Number & $\%$ & Number & $\%$ & Number & $\%$ & \\
\hline Present & 6 & 15.0 & 15 & 37.5 & 21 & 26.3 & $0.02^{\mathrm{S}}$ \\
\hline Absent & 34 & 85.0 & 25 & 62.5 & 59 & 73.7 & \\
\hline
\end{tabular}

Group I= Transradial approach, Group II= Transfemoral approach, $\mathrm{s}=$ Significant $(\mathrm{p}<0.05)$, $\mathrm{p}$ value reached from Chi Square test

\section{Discussions}

In this present study bleeding, vascular complications occurred significantly more in transfemoral approach than transradial approach. Here we found that death, bleeding and other vascular complications occurred less in transradial group in relation to transfemoral group. Other adverse in hospital outcomes were similar in both of the groups. Some previous studies showed a similar reduction in the rate of major bleeding and death. ${ }^{17,18,19}$

Out of 40 patients, $37.5 \%$ patients in group II experienced composite or overall adverse outcome, on the contrary $15 \%$ of the patients in group I did have such experience. So, in this study it was revealed that composite or overall adverse outcome were less in group I than group II with statistically significant association $(\mathrm{p}=0.02)$.

In this study it was observed that the mean hospital stay was significantly low in patient went for transradial approach (4.4 \pm 2.2$)$ than that of transfemoral approach (6.3 \pm 2.9$)$, which resembles with the mean hospital stay ( $5 \pm 3$ days vs. $8 \pm 6$ days, $p<0.05)$ observed by other studies. ${ }^{20,21}$ More recently, the mean hospital stay was found to be $7.0 \pm 7.9$ vs. $7.9 \pm 5.6$ days; $(p<0.005)$ for transradial PCI and transfemoral PCI respectively. ${ }^{22}$ The increased length of hospital stay was probably due to delayed mobilization of the patient and increased rate of vascular complications in primary percutaneous coronary intervention by femoral route.

\section{Limitations of the study}

There are some facts to be considered which might have affected the result of the current study. It was a nonrandomized, single centre study and the study population was small in number. Hemostasis was achieved by using manual pressure in most of the patients.

\section{Conclusion:}

Our findings support that transradial primary PCI is safer than transfemoral in respect of procedural and post procedural complications including bleeding, vascular complications and mortality. More importantly, it has also shorter mean duration of hospital stay. Transradial procedure leads to improve quality of life after the procedure and thus gives much comfort to the patient. So, transradial approach may be an attractive alternative to conventional transfemoral approach and can be practiced routinely for PPCI.

\section{Conflict of Interest - None.}

\section{References:}

1. Valgimigli M, Gagnor A, Calabró P, Frigoli E, Leonardi S, Zaro T, et al. Radial versus femoral access in patients with acute coronary syndromes undergoing invasive management: A randomised multicentre trial. Lancet 2015; 385: 2465-2476.

2. Santucci A, Gargiulo G, Ariotti S, Marino M, Magnani G, Baldo A, et al. Radial versus femoral approach in STEMI: What do we know so far? Minerva Cardioangiol 2016; 64: 219-237.

3. Ruiz-Rodriguez E, Asfour A, Lolay G, Ziada KM, AbdelLatif AK. Systematic Review and Meta-Analysis of Major Cardiovascular Outcomes for Radial Versus Femoral Access in Patients With Acute Coronary Syndrome. South Med J 2016; 109: 61-76.

4. Rao SV, Turi ZG, Wong SC, Brener SJ, Stone GW. Radial versus femoral access. J Am Coll Cardiol 2013; 62: S11-20.

5. Piccolo R, Galasso G, Capuano E, Luca S de, Esposito G, Trimarco B, et al. Transradial versus transfemoral approach in patients undergoing percutaneous coronary intervention for acute coronary syndrome. A meta-analysis and trial sequential analysis of randomized controlled trials. PLoS One 2014; 9: e96127. 
6. Pandie S, Mehta SR, Cantor WJ, Cheema AN, Gao P, Madan M, et al. Radial Versus Femoral Access for Coronary Angiography/Intervention in Women With Acute Coronary Syndromes: Insights From the RIVAL Trial (Radial Vs femorAL access for coronary intervention). JACC Cardiovasc Interv 2015; 8: 505-512.

7. Paitry S, Savage M, Murdoch D, Raffel C, Walters D. Radial Versus Femoral Access in ST-Segment Elevation Myocardial Infarction Patients Treated by Primary Percutaneous Coronary Intervention. Heart Lung and Circ 2016; 25: S192.

8. Meier P, Windecker S, Lansky AJ. Radial versus femoral access for primary percutaneous coronary intervention: Is there a preferred route to the heart? Heart 2012; 98: 269270 .

9. Marti V, Brugaletta S, García-Picart J, Delgado G, Cequier A, Iñiguez A, et al. Radial versus femoral access for angioplasty of ST-segment elevation acute myocardial infarction with second-generation drug-eluting stents. Rev Esp Cardiol (Engl Ed) 2015; 68: 47-53.

10. Liu P, Gao XL, Li BF, Ding XZ, Wang ZH, Dang YP, et al. Radial versus femoral artery access for percutaneous coronary angiography and intervention: A systematic review and meta-analysis of randomized controlled trials in Chinese population. Int J Clin Exp Med 2015; 8: 17151-17166.

11. Lee MS, Wolfe M, Stone GW. Transradial versus transfemoral percutaneous coronary intervention in acute coronary syndromes: Re-evaluation of the current body of evidence. JACC Cardiovasc Interv 2013; 6: 1149-1152.

12. Kolte D, Spence N, Puthawala M, Hyder O, Tuohy CP, Davidson CB, et al. Association of radial versus femoral access with contrast-induced acute kidney injury in patients undergoing primary percutaneous coronary intervention for ST-elevation myocardial infarction. Cardiovasc Revasc Med 2016; 17: 546-551.

13. Agostoni P, Biondi-Zoccai GGL, Benedictis ML de, Rigattieri S, Turri M, Anselmi M, et al. Radial versus femoral approach for percutaneous coronary diagnostic and interventional procedures; Systematic overview and metaanalysis of randomized trials. J Am Coll Cardiol 2004;44:349-356.

14. Kedev S, Sukmawan R, Kalpak O, Dharma S, Antov S, Kostov J, et al. Transradial versus transfemoral access for female patients who underwent primary PCI in STEMI: Two years follow-up data from acute STEMI interventional registry. Int J Cardiol 2016; 217 Suppl: S16-20.
15. Karrowni W, Vyas A, Giacomino B, Schweizer M, Blevins A, Girotra S, et al. Radial versus femoral access for primary percutaneous interventions in ST-segment elevation myocardial infarction patients: A meta-analysis of randomized controlled trials. JACC Cardiovasc Interv 2013; 6: 814-823.

16. Kadakia MB, Rao SV, McCoy L, Choudhuri PS, Sherwood MW, Lilly S, et al. Transradial Versus Transfemoral Access in Patients Undergoing Rescue Percutaneous Coronary Intervention After Fibrinolytic Therapy. JACC Cardiovasc Interv 2015; 8: 1868-1876.

17. Jolly SS, Yusuf S, Cairns J, Niemelä K, Xavier D, Widimsky $\mathrm{P}$, et al. Radial versus femoral access for coronary angiography and intervention in patients with acute coronary syndromes (RIVAL): A randomised, parallel group, multicentre trial. Lancet 2011; 377: 1409-1420.

18. Graham JJ, Yan AT, Tan MK, Cantor WJ, DiMario C, Jolly SS, et al. Radial versus femoral access for percutaneous coronary intervention in ST-elevation myocardial infarction patients treated with fibrinolysis: Results from the randomized routine early invasive clinical trials. Cardiovasc Revasc Med 2016; 17: 295-301.

19. Dobies DR, Barber KR, Cohoon AL. Analysis of safety outcomes for radial versus femoral access for percutaneous coronary intervention from a large clinical registry. Open Heart 2016; 3: e000397.

20. Cortese B, Sciahbasi A, Sebik R, Rigattieri S, Alonzo A, Silva-Orrego P, et al. Comparison of risk of acute kidney injury after primary percutaneous coronary interventions with the transradial approach versus the transfemoral approach (from the PRIPITENA urban registry). Am J Cardiol 2014; 114: 820-825.

21. Chiang A, Gada H, Kodali SK, Lee MS, Jeremias A, Pinto DS, et al. Procedural variation in the performance of primary percutaneous coronary intervention for ST-elevation myocardial infarction: A SCAI-based survey study of US interventional cardiologists. Catheter Cardiovasc Interv 2014; 83: 721-726.

22. Cantor WJ, Ko DT, Natarajan MK, D• avík V, Wijeysundera HC, Wang JT, et al. Reperfusion Times for Radial Versus Femoral Access in Patients With ST-Elevation Myocardial Infarction Undergoing Primary Percutaneous Coronary Intervention: Observations From the Cardiac Care Network Provincial Primary PCI Registry. Circ Cardiovasc Interv 2015; 8:e002097. 